\title{
Publish or Perish: A Dilemma For Academic Librarians?
}

\section{W. Bede Mitchell and Mary Reichel}

This study examines the influence of scholarly requirements on librarians' ability to earn tenure or continuous employment. After a literature review, the authors present the results of a survey of research, doctoral, and master's-level institutions. Of the 690 responding institutions, 54.3 percent employ tenure-track librarians. Of these, more than 60 percent require some scholarship and 34.6 percent encourage it. At these 374 institutions, 92.2 percent of librarians who underwent tenure review during a three-year period were approved. The authors summarize survey information on librarians not granted tenure as well as those believed by directors to have resigned to avoid tenure review.

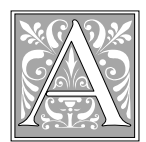

persistent concern in the faculty status movement has been whether tenure-track librarians will be able to establish records of research and publication that meet their institutions' overall promotion and tenure criteria. Many contend that requiring academic librarians to divert their energies from their daily duties to meet research expectations is inappropriate. This article does not examine this debate except as it affects consideration of the following question: Is there evidence that librarians with faculty status will be less likely to meet tenure requirements than other faculty?

One of the most common objections to faculty status for librarians has been that the benefits are outweighed by the diffi- culties inherent in meeting tenure-track requirements. More specifically, many writers have expected that, for better or worse, librarians with faculty status typically will be required to meet the traditional faculty criterion of research and publication. ${ }^{1}$ Support for this belief was strengthened when a committee of representatives from the Association of College and Research Libraries, the Association of American Colleges, and the American Association of University Professors drafted the "Joint Statement on Faculty Status for College and University Librarians." ${ }^{2}$ This statement stipulated that librarians should be held to the same evaluation standards as other faculty.

The idea that librarians might be required to meet faculty research require-

W. Bede Mitchell and Mary Reichel are, respectively, Associate University and University Librarian in Belk Library; and Professors at Appalachian State University; e-mail: mitchellwb@appstate.edu and reichelml@appstate.edu. 
ments has been viewed positively by some and with alarm by others. According to Dale S. Montanelli and Patricia F. Stenstrom, research offers many benefits to librarians and the institutions they serve. ${ }^{3}$ For example, the complexities of managing efficient and effective library service are likely to be better addressed through discoveries made from systematic, well-designed research. Research also promotes advancement and recognition for librarians. In addition, librarians who regularly do research are thought to be more receptive to change and have more effective relationships with other faculty than do those who do not do research.

\section{The idea that librarians might be required to meet faculty research requirements has been viewed positively by some and with alarm by others.}

On the other hand, surveys and opinion pieces published in library journals have demonstrated that many inside and outside the library profession believe that applying faculty performance standards to librarians (especially a research requirement) is inappropriate and dangerous. ${ }^{4}$ One reason given for thinking that librarians should not be judged by faculty performance criteria is that librarians tend to lack the education and the opportunities to perform research that would meet standards acceptable to institutional tenure committees. The result would be a "forced mobility" among librarians, which in turn would have a devastating effect on the morale of the academic library profession. ${ }^{5}$ Therefore, many librarians would find it unreasonable to be expected to perform day-to-day duties while also doing research and meeting service expectations. $^{6}$

If it is true that librarians tend to be unable to perform high-level research, why should this be so? The two reasons most commonly offered are that (1) most graduate library degree programs do not teach students to perform the kind of research tenure committees expect and (2) nonlibrary faculty members have much more time to pursue research because librarians are usually tied to forty-hour workweeks and full-year contracts. ${ }^{7}$ Thus, the difference in the amount of available research time would make it difficult for librarians to match the quantitative production standards of other faculty, to say nothing of the qualitative standards. Unfortunately, as many writers have pointed out, academic-year contracts for librarians are usually out of the question because the work of a library continues during the summer months. ${ }^{8}$

To compensate for the problem that full-year contracts and rigid weekly schedules might create for librarians attempting to do research, a number of institutions have allowed released time (some prefer the term "reassigned time") for graduate classwork and research projects, and some have appointed staff development committees that review and advise on research projects. ${ }^{9}$ At least one university has implemented a system for providing scheduling equity with nonlibrarian faculty based on Credit Unit Equivalencies. ${ }^{10}$ However, Shelley Arlen and Nedria Santizo found that arrangements to create reassigned time for research were the exception rather than the rule. ${ }^{11}$

Even if research reassignments for librarians were common, many would still contend that librarians do not have the training necessary to meet research requirements for promotion and tenure. If this is true, one would expect there to be empirical evidence that large numbers of librarians are failing to meet promotion and tenure requirements. A number of previous studies address this issue, at least in part.

\section{Previous Studies}

A number of researchers have examined librarians' publication productivity. Virgil F. Massman offered a comparison of publishing productivity by librarians and instructional faculty after surveying 224 librarians and 205 faculty members in three midwestern states. ${ }^{12}$ The faculty members proved to be more productive, publish- 
ing an average of 1.7 articles per person over a two-year period as compared to the .7 articles per librarian over the same two-year period. Because Massman did not address the issue of whether the librarians' publication records had harmed their tenure applications, the data are only suggestive of a potential problem. Similarly, Paula De Simone Watson looked at the publication activity of librarians at ten large research universities and concluded, as did Massman, that librarians tended not to publish as much as instructional faculty. ${ }^{13}$ Of particular concern to Watson was the low productivity of librarians with five or fewer years of professional experience. Because probationary periods for tenure are commonly five to seven years, the low productivity among newcomers to the field suggested that they might have difficulty gaining tenure, resulting in the "forced mobility" feared by some. The same concern was echoed by a majority of academic administrators surveyed by Thomas G. English, whereas John Campbell provided personal insight into his own termination due to lack of publications. ${ }^{14-15}$

On the other hand, four studies seem to indicate that low publishing productivity has not been a substantial barrier to librarians seeking tenure. First, Karen F. Smith and Gemma DeVinney found that of 526 tenured librarians at thirty-three major research libraries, $248(47.1 \%)$ had not published anything as of the date they had been granted tenure. ${ }^{16}$ Second, although the W. Bede Mitchell and L. Stanislava Swieszkowski survey of Center for Research Libraries member institutions discovered that the most frequent cause of librarians being rejected for tenure was reported to be an inadequate publication record, it also was the case that 81.5 percent of the 329 librarians who applied for tenure between 1980 and 1984 were successful. ${ }^{17}$ This tenure approval rate contrasted sharply with the 58 percent success rate of faculty applicants reported in a 1978-1979 national survey of tenure approval rates. ${ }^{18}$

In the third study in question, Mitchell attempted to obtain a more direct comparison between the tenure approval rates of library and nonlibrary faculty by conducting a survey of library directors and academic affairs administrators at universities classified by the Carnegie Foundation for the Advancement of Teaching as Doctorate-Granting Institutions I and II. ${ }^{19}$ The survey identified thirty-five institutions where librarians had tenure-track status, and the responses from those institutions were sorted according to the independent variables to be studied for their possible association with tenure approval rates of academic librarians. The independent variables were academic-year contract versus full-year contract, and whether librarians had to show evidence of research and publication to earn tenure. The academic administrators at the institutions where librarians had tenure-track status were asked how many instructional faculty and librarians were formally reviewed for tenure and how many were granted tenure in the three years prior to the survey (1985-1986, 1986-1987, 1987-1988).

Seventeen universities reported having librarians reviewed for tenure during the three years in question. An analysis of the tenure data tested the theory that librarians were more likely to be turned down for tenure than were instructional faculty, especially where librarians have full-year contracts and must meet publication requirements. Unfortunately, no tenure data were available from the few universities where the librarians held academic-year contracts. However, the rest of the data did prove to be very revealing and may have made the lack of data concerning librarians on academic-year contracts moot.

Table 1 shows that at the responding universities, the librarians achieved tenure at almost identical rates as the instructional faculty. This held true whether all the librarians were compared to all the instructional faculty, whether only the librarians required to publish were compared to the instructional faculty at their institutions, or whether the librarians not required to publish were compared to the 


\begin{tabular}{|lccc}
\hline \multicolumn{3}{c}{ TABLE 1 } \\
Tenure Approval Comparisions, Mitchell (1989) \\
\hline & Tenured & Rejected & Total \\
\hline Instructional faculty & 670 & 104 & 774 \\
& $(86.6 \%)$ & $(13.4 \%)$ & \\
Publishing librarians & 39 & 7 & 46 \\
& $(84.8 \%)$ & $(15.2 \%)$ & \\
& 238 & 47 & 285 \\
Instructional faculty & $(83.5 \%)$ & $(16.5 \%)$ & \\
& 12 & 2 & 14 \\
Non-publishing librarians & $(85.7 \%)$ & $(14.3 \%)$ & \\
& & 151 & 1,059 \\
& 908 & $(14.3 \%)$ & \\
\hline All instructional faculty & $(85.7 \%)$ & 9 & 60 \\
All librarians & 51 & $(15.0 \%)$ & \\
& $(85.0 \%)$ &
\end{tabular}

instructional faculty at their institutions. With that in mind, it is obvious that librarians required to publish achieved tenure at very similar rates as librarians not required to publish. It also may be fair to speculate that contract type did not interfere unduly with the librarians' efforts to achieve tenure because all the librarians represented in table 1 held the full-year contracts that many feared would be impediments. The tenure approval data reported herein are very similar to the data found in the research Mitchell did with Swieszkowski. The data in that study showed librarians being approved for tenure at a rate of 81.5 percent, compared to the 85 percent approval rate found in this study.

In the fourth study relevant to the discussion, Elizabeth C. Henry, Dana M. Caudle, and Paula Sullenger found that at ninety-four surveyed academic libraries, there was a 93 percent tenure approval rate for the librarians. ${ }^{20}$ The authors also compared the turnover rates of librarians at libraries with tenure requirements to those of libraries without tenure requirements, and concluded:

that having librarians meet tenure-track requirements does not significantly increase or decrease the turnover rates for professional staff.
In fact, those libraries that had high turnover rates were more likely not to have tenure requirements. ${ }^{21}$

Thus, the limited tenure approval data from previous studies show that librarians have been gaining tenure at rates that are similar to, or higher than, the approval rates of the instructional faculty at the same universities.

\section{The Current Study}

The present study sought the most recent success rates of librarians in earning tenure, especially at institutions that require or encourage evidence of scholarship. The authors conducted a survey of 759 academic libraries at the institutions that are classified in the latest Carnegie Foundation study as Research I or II, Doctoral I or II, or Master's (formerly Comprehensive) I or II..$^{22}$ There are 768 research, doctoral, and master's institutions; all were sent questionnaires except for nine MA IIs for which current information was not readily obtainable. After several follow-up mailings, a return rate of 90.9 percent ( 690 of 759 institutions) was achieved.

The library directors at the surveyed institutions were asked to provide some basic profile data and information on recent tenure reviews. The study authors inquired about tenure reviews and not pro- 
motion reviews, in part due to the finality and seriousness of tenure denials and in part to avoid making the survey so lengthy that it would discourage a

\begin{tabular}{|cccccc|}
\hline \multicolumn{7}{|c|}{ TABLE 2 } \\
\hline \hline Distribution of Responses \\
\hline 81 of 88 & 32 of 37 & 44 of 52 & 52 of 59 & 401 of 439 & 80 of 93 \\
$(92.0 \%)$ & $(86.5 \%)$ & $(84.6 \%)$ & $(88.1 \%)$ & $(91.3 \%)$ & $(86.0 \%)$ \\
\hline
\end{tabular}

high return rate.

Responses were sorted initially according to whether the institutions employed librarians in tenure-track positions. Included in this category were institutions that did not offer tenure to librarians but have a continuing employment status that is awarded if the librarians meet expectations during a probationary period. The institutions with tenure-track or continuing employment status (which for the sake of brevity are lumped together here as having tenure-track status) were asked to indicate whether evidence of scholarship is required, encouraged, or given little or no weight when librarians are reviewed for tenure. They then were asked to indicate how many librarians underwent their tenure reviews during the three-year period of 1995-1996, 19961997, and 1997-1998 (this mirrors the three-year period used in Mitchell's 1989 study); and of those librarians, how many were approved at all review levels or at the highest level only and how many were rejected at all levels or at the highest level only. Finally, the library directors were asked if they knew how many of the rejections were due primarily to inadequate scholarly records and if they knew of any librarians who had left their employ during the specified time period primarily because of an unwillingness to undergo tenure review.

Within the 690 responses received, more than 84 percent of the institutions in each selected Carnegie classification were represented (see table 2). Of the 690 responding institutions, $374(54.2 \%)$ reported having tenure-track librarians (see table 3). Interestingly, there is a marked division within each Carnegie classification between public and private institutions as to whether the librarians are tenure-track. Of the 374 universities where librarians are tenure-track, 74.6 percent are public institutions. But of the 316 universities where librarians are not tenuretrack, only 32.9 percent are public institutions. It is also worth noting here that these figures are not necessarily comparable to statistics gathered in studies that have attempted to determine how widespread faculty status for librarians is. Some institutions consider themselves to have faculty status for librarians, even though the librarians do not have tenuretrack appointments.

Table 4 shows the breakdown by Carnegie classification and public/private status of the weight given to scholarship in tenure reviews. One data point was irretrievable, so of the remaining 373 institutions where librarians are tenure-track,

\begin{tabular}{|lrrr|}
\hline \multicolumn{4}{c}{ TABLE 3 } \\
Tenure/Non-tenure Distribution & \\
\hline \hline & \multicolumn{1}{c}{ Tenure } & No Tenure & Total \\
\hline Res I \& II, Public & $61(79.2 \%)$ & $16(20.8 \%)$ & 77 \\
Res I \& II, Private & $6(16.7 \%)$ & $30(83.3 \%)$ & 36 \\
Doc I \& II, Public & $37(67.3 \%)$ & $18(32.7 \%)$ & 55 \\
Doc I \& II, Private & $10(23.8 \%)$ & $32(76.2 \%)$ & 42 \\
MA I \& II, Public & $181(72.1 \%)$ & $70(27.9 \%)$ & 251 \\
MA I \& II, Private & $79(34.5 \%)$ & $150(65.5 \%)$ & 229 \\
\hline Totals & $374(54.2 \%)$ & $316(45.8 \%)$ & 690 \\
\hline
\end{tabular}
60.9 percent require some evidence of scholarship, 34.6 percent encourage it, and 4.6 percent give it little or no weight.

The responding institutions re- 


\begin{tabular}{|lccc|}
\hline \multicolumn{4}{c|}{ TABLE 4 } \\
Weight of Scholarship in Tenure Reviews \\
\hline \hline & Required & Encouraged & Little/No Weight \\
\hline Res I \& II, Public & 35 & 26 & 0 \\
Res I \& II, Private & 4 & 2 & 0 \\
Doc I \& II, Public & 19 & 15 & 3 \\
Doc I \& II, Private & 6 & 4 & 0 \\
MA I \& II, Public & 124 & 50 & 7 \\
MA I \& II, Private & 39 & 32 & 7 \\
\hline Totals & 227 & 129 & $17=373$ \\
& $(60.9 \%)$ & $(34.6 \%)$ & $(4.6 \%)$ \\
\hline
\end{tabular}

sion were more tortuous-for example, approved by library review committee, rejected by library director, approved or rejected at the university committee level, and ultimately ap-

ported that for the three-year period in question, 92.2 percent of all librarians who underwent their tenure reviews were ultimately approved, with most being approved at all levels where there is more than one review level (e.g., library review and university promotion and tenure committee). Some respondents recorded a few reviews whose paths to final deci- proved or rejected by whatever the campus's final deciding authority is. These few cases were rolled into the categories $\mathrm{C}$ and $\mathrm{F}$ in table 5 .

As Table 5 shows, the tenure approval rates at all types of academic libraries are high and very similar to those found in 1985, 1989, and 1994 by Mitchell and Swieszkowski $(81.5 \%)$, Mitchell $(85 \%)$,

\begin{tabular}{|c|c|c|c|c|c|c|c|}
\hline \multicolumn{8}{|c|}{$\begin{array}{c}\text { TABLE } 5 \\
\text { Tenure Review Data }\end{array}$} \\
\hline & A C & B D & & & $\mathrm{E}$ & $\mathrm{F}$ & G \\
\hline Res I \& II, Public & 325 & 293 & 1 & $90.5 \%$ & 19 & 12 & (16) \\
\hline Res I \& II, Private & 32 & 26 & 1 & $84.4 \%$ & 3 & 2 & (2) \\
\hline Doc I \& II, Public & 124 & 111 & 4 & $92.7 \%$ & 8 & 1 & $(0)$ \\
\hline Doc I \& II, Private & 27 & 24 & 0 & $88.9 \%$ & 2 & 1 & (2) \\
\hline MA I \& II, Public & 255 & 243 & 0 & $95.3 \%$ & 8 & 4 & (8) \\
\hline MA I \& II, Private & 81 & 74 & 1 & $92.6 \%$ & 0 & 6 & (4) \\
\hline Totals & 844 & 771 & 7 & $92.2 \%$ & 40 & 26 & $(32)$ \\
\hline \multicolumn{8}{|c|}{$A=$ Number of tenure reviews } \\
\hline \multicolumn{8}{|c|}{$B=$ Number approved at all levels } \\
\hline \multicolumn{8}{|c|}{$\mathrm{C}=$ Number approved ultimately despite negative recommendation(s) at lower level(s) } \\
\hline \multicolumn{8}{|c|}{$\mathrm{D}=$ Tenure approval rate } \\
\hline \multicolumn{8}{|c|}{$\mathrm{E}=$ Number rejected at all levels } \\
\hline \multicolumn{8}{|c|}{$\mathrm{F}=$ Number rejected ultimately despite positive recommendation(s) at lower level(s) } \\
\hline \multicolumn{8}{|c|}{$\mathrm{G}=$ Number of rejections that were thought to be primarily due to inadequate scholarly records } \\
\hline \multicolumn{8}{|c|}{$\begin{array}{l}\text { Of the thirty-two rejected primarily for inadequate scholarly records, thirty-one worked at } \\
\text { institutions where scholarship is required (out of } 509 \text { total librarians reviewed, or } 6.1 \% \text { ) and } \\
\text { one worked where scholarship is encouraged (out of } 319 \text { total librarians reviewed, or } 0.3 \% \text { ). }\end{array}$} \\
\hline \multicolumn{8}{|c|}{$\begin{array}{l}\text { Forty-one institutions reported one or more librarians being rejected for tenure during the } \\
\text { three years under review. Eighteen institutions reported librarians being rejected for tenure } \\
\text { primarily due to inadequate scholarly records: eleven reported one librarian, four reported } \\
\text { two librarians, two reported three librarians, one reported seven librarians. }\end{array}$} \\
\hline
\end{tabular}


and Henry, Caudle, and Sullenger (93\%). Unfortunately, the study authors did not find comparative tenure approval data for other disciplines in the professional literature. Thus, it is unclear how the librarian tenure approval data compare to the rates of other faculty.

Of the sixty-six librarians who were not granted tenure, thirty-two (48.5\%) were thought by the library directors to have been turned down primarily due to inadequate scholarly records. Of those thirty-two, thirty-one were rejected out of 509 librarians reviewed at institutions where scholarship is required $(6.1 \%)$ and only one was rejected out of 319 librarians reviewed at universities where scholarship is encouraged. It must be remembered that this analysis is tentative because reasons for tenure application rejections are not typically public knowledge, nor would library directors themselves always know the exact reasons for rejection, depending on the tenure review procedures under which they are working. Given that caveat, it is still worth noting that fewer than half of the tenure rejections were thought to be due to inadequate scholarly records.

Another set of data that cannot be compared due to lack of similar research in other disciplines is the number of librarians who resigned rather than be reviewed for tenure (see table 6). The responses to this question must be considered nothing more than an approximation of the actual figure, for clearly library directors will not necessarily know the precise reasons for resignations in all cases. However, given that a number of people have speculated that tenure requirements such as scholarship would hurt the library profession's ability to retain librarians in ways that would not show up in tenure reviews, the authors thought it would be interesting to seek the information, even if the result would be only an approximation and comparative data for other faculty did not exist. So what, if anything, can be made of the results in table 6 ?

It must be remembered that although the eighty-eight librarians were thought to have resigned to avoid tenure review, it is not known for certain that it was the scholarship aspect of the tenure review that caused the resignations. Some of the eighty-eight may have thought their service records, daily job performances, or other factors were not going to be acceptable to the tenure review committees. But even if that fact is set aside and the eightyeight are treated as if they all resigned due to scholarly expectations, the overall impact on the tenure approval data is not large. If the 88 are added to the total of 844 librarians who were reviewed for tenure, 778 approvals out of 932 is 83.5 percent, which is still an impressive approval rate.

\section{Further Discussion}

As previously noted, there appears to be no similar research that examines tenure success rates of other faculty. However, in light of the aforementioned findings, it is highly likely that academic li-

Note: Of the fifty-two institutions reporting, thirty-two reported one librarian, thirteen reported two librarians, four reported three librarians, one reported four librarians, one reported six librarians, and one reported eight librarians. 
brarians are doing as well or better overall than their instructional counterparts, regardless of the kind of institution at which they work (e.g., research, master's, or doctoral).

Some might speculate that librarians whose tenure applications appear weak

\section{An interesting topic for future research is whether library directors are more active in providing guid- ance and support to probationary faculty than are other academic deans or chairs.}

are less likely than weak faculty in other disciplines to have their applications forwarded to university tenure review committees. Although the authors found nothing in the literature that supports this notion, some comments from respondents to this study relate to it. Some library directors indicated they took responsibility for mentoring tenure-track librarians in their pursuit of tenure. An interesting topic for future research is whether library directors are more active in providing guidance and support to probationary faculty than are other academic deans or chairs. A related theory meriting investigation is whether librarians with weak records are more likely to be terminated prior to final tenure review than are other faculty. Several respondents to this study reported that potentially unsuccessful candidates did not normally reach final tenure review.

Regarding the issue of librarian work schedules, the results of this and previous tenure success studies show that forty-hour workweeks and full-year contracts are not preventing many librarians from achieving tenure. However, some might argue that their work schedules mean that librarians have to make more substantial personal sacrifices than nonlibrarian faculty in order to earn tenure. On the contrary, Robert Boice, Jordan M. Scepanski, and Wayne Wilson found that lack of time was no greater a problem for librarians struggling to do research at one particular university than it was for the other faculty at that university. ${ }^{23}$ They compared librarians' methods of coping with pressures to publish with the methods adopted by instructional faculty members and concluded that the publishing efforts of both librarians and instructional faculty suffered less from actual lack of time than from insecurities, entrenched work habits, inefficient use of time, and unsupportive workplace cultures. In short, the instructional faculty and the librarians suffered from similar problems, and yet "both groups evidenced sufficient time for scholarship amid busy schedules." ${ }^{24}$ The key to productivity lies in learning to write during short time spans, a proven technique that explodes the myth commonly held by instructional faculty and librarians that effective writing requires large blocks of time..$^{25-26}$

Two other studies speak somewhat less directly to the issue of librarians' productivity and time factors, but they do not conflict with Boice, Scepanski, and Wilson's conclusion. In Massman's study, there was no statistically significant difference between the quantity of publications by librarians with academic-year contracts and those with full-year contracts. ${ }^{27}$ Dwight F. Burlingame and Joan Repp surveyed 220 actively publishing librarians, most of whom had not found release time to be an important stimulus to publication efforts. ${ }^{28}$ These older studies seem to support Boice, Scepanski, and Wilson's conclusion that librarians who want to publish find the time to do so and that librarians who publish very little are most affected by factors other than lack of time.

Finally, there are two points to be made in response to those who have difficulty reconciling the high librarian tenure approval data with their expectations that librarians are struggling to meet faculty publication requirements. First, as R. Dean Galloway wrote in 1979, librarians and members of the general population harbor exaggerated perceptions of the amount of publishing required of fac- 
ulty. ${ }^{29}$ Despite methodological problems, an important point that emerges from virtually all of the studies on faculty publishing is that "the great majority of academics do surprisingly little research," and both Mary Biggs and Charles Schwartz offered substantial evidence supporting that assertion by citing numerous surveys of faculty in postsecondary institutions. ${ }^{30-31}$

Second, there are exaggerated perceptions about the amount of publication that has been and is now required of tenure-track librarians. Historically, publication requirements for librarians have been limited. In the 1980s, several surveys discovered that the majority of institutions where academic librarians had tenure-track status did not require the librarians to show much or any evidence of research and publication. ${ }^{32}$ At about the same time, John M. Budd and Charles A. Seavey examined the articles published during 1983-1987 in thirty-six journals that were "national in scope" and found that 384 academic libraries could claim an author of at least one article..$^{33}$ As Budd and Seavey pointed out, 384 institutions is only 18.3 percent of the four-year institutions of higher learning in the United States. The authors suggested that this provided further evidence that publication requirements were not widespread.

At the end of the 1980s, Betsy Park and Robert Riggs elicited responses from a stratified sample of institutions from each Carnegie Foundation category and found that only about one-third of the responding schools with librarian tenure-track status required librarians to publish in order to earn promotion or tenure. ${ }^{34}$

Although the present study has found there has been a major shift and a majority of institutions with tenure-track librarians now do require evidence of scholarship for tenure (see table 4), the amount of scholarship may range greatly. In any event, the scholarly requirement appears not to have been a major impediment given the high librarian tenure approval rates, except perhaps at a very few insti- tutions. These findings are consistent with Charles B. Lowry's national survey, dating from the early $1990 \mathrm{~s} .{ }^{35}$ He stated:

In general, this research concludes that application of the criteria for promotion and tenure of librarians has been realistically adapted to the needs of the library in the academic setting and the kinds of assignments that librarians receive. ${ }^{36}$

The idea of adapting promotion and tenure criteria to the particular needs and circumstances of each discipline is gaining support in many circles, partly as a result of the recent "redefining scholarship" movement in which the ACRL has participated. ${ }^{37}$

Thus, it is possible to conclude that: The belief that librarians must publish or perish may be based on anecdotal evidence or on a few highly publicized cases, rather than established as fact. ${ }^{38}$

The existing evidence shows that most tenure-track librarians are meeting tenure standards at the same or higher rate as instructional faculty. There is a notable lack of empirical support for the notion that librarians fail disproportionately to meet tenure standards (at either the university level or some lower review level) or choose to leave prior to final tenure review at higher rates than do other faculty. However, although there is some evidence of problems in achieving tenure at certain institutions, there is no reason to conclude that they are widespread among similar institutions. In fact, the findings of this study clearly indicate otherwise.

\section{Conclusion}

The findings reviewed in the foregoing indicate that although most librarians tend not to publish frequently, as a group, they do not have notable problems in achieving tenure. However, it would be helpful to replicate the tenure approval studies, at both the Carnegie classifications not 
included in this study and the institutions included herein. In the latter case, further longitudinal data would indicate whether there was something very out of the ordinary about the three-year period investigated in this study, even though the data are very consistent with the figures collected in 1985 (Mitchell and Swieszkowski), 1989 (Mitchell), and 1993 (Henry, Caudle, and Sullenger). Research on librarian promotion success rates also would be useful because even if achieving tenure is not more difficult for librarians than instructional faculty, perhaps librarians have more trouble being promoted.

Moreover, more work might be done on the hypothesis that where publication is required for librarians to achieve tenure, it acts as a significant stimulus to pub- lication activity. On the one hand, Paula D. Watson found that publication requirements were imposed on the librarians at 42 percent of academic libraries whose librarians were productive publishers, but Aubrey Kendrick's examination of the publication records of one kind of academic librarian (business librarians) turned up no statistically significant difference in productivity between those who had faculty rank and those who did not. ${ }^{39-40}$

Until future studies turn up findings to the contrary, the preponderance of evidence in the professional literature creates a presumption that faculty status does not lead to publication requirements that severely harm the chances of academic librarians to achieve tenure.

\section{Notes}

1. Willis Bridegam, "A Research Requirement for Librarians?" Journal of Academic Librarianship 4 (July 1978): 135-36; Nancy Davey and Theodora Andrews, "Implications of Faculty Status for University Librarians, with Special Attention to Tenure," Journal of Academic Librarianship 4 (May 1978): 71-74; Richard M. Dougherty, "Faculty Status—A Sharp Two-Edged Sword," Journal of Academic Librarianship 1 (July 1975): 3; Carl Hintz, "Criteria for Appointment to and Promotion in Academic Rank," College \& Research Libraries 29 (Sept. 1968): 341-46; Frederick Isaac, "Librarian, Scholar, or Author? The Librarian's New Dilemma," Journal of Academic Librarianship 9 (Sept. 1983): 216-220; Arthur M. McAnally, "Privileges and Obligations of Academic Status," College E Research Libraries 24 (Mar. 1963): 102-8; John H. Moriarty, "Academic in Deed," College \& Research Libraries 31 (Jan. 1970): 14-17; Robert M. Pierson, Letter, American Association of University Professors Bulletin 53 (June 1967): 249-50; _ _ "The Proposed Standards for Faculty Status: A Dissenting Opinion," College E Research Libraries News 32 (May 1971): 121--25; T. M. Schmid, "Shoemaker, stick...," Journal of Academic Librarianship 4 (July 1978): 136-37; Russell H. Seibert, "Status and Responsibilities of Academic Librarians," College \& Research Libraries 22 (July 1961): 253--55.

2. Joint Committee on College Library Problems, "Joint Statement on Faculty Status of College and University Librarians," College \& Research Libraries 33 (Sept. 1972): 209-10.

3. Dale S. Montanelli and Patricia F. Stenstrom, "The Benefits of Research for Academic Librarians and the Institutions They Serve," College E Research Libraries 47 (Sept. 1986): 482-85.

4. Thomas G. English, "Administrators' Views of Library Personnel Status," College $\mathcal{E}$

Research Libraries 45 (May 1984): 189-95; Richard W. Meyer, "Faculty Status and Academic Librarians: Are There Second Thoughts?" North Carolina Libraries 39 (winter 1981): 41-47; Wilfrid Bede Mitchell, Faculty Status for Academic Librarians: Compliance with Standards, Opinions of University Administrators, and a Comparison of Tenure-Success Records of Librarians and Instructional Faculty (Ed.D. Diss., Montana State University,1989; Ann Arbor, Mich.: University Microfilms International, 1989), 89-25, 784; Moriarty, "Academic in Deed," 14-17; Sherman E. Pyatt, Josephine B. Williamson, and Edgar Williamson, "Faculty Status in South Carolina," College \& Research Libraries News 50 (Nov. 1989): 927-33; Beth J. Shapiro, "The Myths Surrounding Faculty Status for Librarians," College \& Research Libraries News 54 (Nov. 1993): 562-63.

5. Rita Sparks, "Tenure: Solution or Problem," Michigan Librarian 41 (fall 1975): 9-10.

6. Ellsworth Mason, "A Short Happy View of Our Emulation of Faculty," College \& Research Libraries 33 (Nov. 1972): 445-46; ——, Letter, College \& Research Libraries 34 (May 1973): 224; Pierson, Letter, 249--50; Steven E. Rogers and Linda K. Butler, "Academic Librarians and Faculty Evaluations: A Case for Equity," Tennessee Librarian 45 (summer 1993): 11-17; Pauline Wilson, "Librarians as Teachers: The Study of an Organizational Fiction," Library Quarterly 49 (Apr. 1979): 146-62.

7. H. William Axford, "The Three Faces of Eve, or the Identity of Academic Librarianship," 
Journal of Academic Librarianship 2 (Jan. 1977): 276--78; Marjorie A. Benedict, “Librarians' Satisfaction with Faculty Status," College \& Research Libraries 52 (Nov. 1991): 538--48; Fay M. Blake, "Faculty Status: Where It's At," American Libraries 1 (Sept. 1970): 767-68; _ _ Letter, College \& Research Libraries 34 (Mar. 1973): 159-60; Bridegam, "A Research Requirement for Librarians?" 135--36; Harry R. Gates, "The Academic Status Illusion and the Nine-Month Contract," Pacific Northwest Library Association Quarterly 36 (Jan. 1972): 3-6; Hintz, "Criteria for Appointment," 341-46; Guy Lyle, The President, the Professor, and the College Library (New York: H. W. Wilson, 1963); W. Bede Mitchell and Bruce Morton, "On Becoming Faculty Librarians: Acculturation Problems and Remedies," College $\mathcal{E}$ Research Libraries 53 (Sept. 1992): 379-92; Eli M. Oboler, Letter, College \& Research Libraries 34 (Jan. 1973): 69-70; Pyatt, Williamson, and Williamson, "Faculty Status in South Carolina," 927-33; Sharon Lee Stewart, "Publication Requirements for Academic Librarians: A Snapshot of the Big Picture," Southeastern Librarian 43 (spring/summer 1993): 11-13.

8. Fred Batt, "Faculty Status for Academic Librarians: Justified or Just a Farce?" in Issues in Academic Librarianship, ed. Peter Spyers-Duran and Thomas W. Mann Jr. (Westport, Conn.: Greenwood, 1985), 115--28; Stella Bentley, "Collective Bargaining and Faculty Status," Journal of Academic Librarianship 4 (May 1978): 75-81; Russ Davidson, Connie Capers Thorson, and Diane Stine, "Faculty Status for Librarians: Querying the Troops," College E Research Libraries 44 (Nov. 1983): 414-20; Ronald F. Dow, "Academic Librarians: A Survey of Benefits and Responsibilities," College E Research Libraries 38 (May 1977): 218-20; English, "Administrators' Views of Library Personnel Status," 199-211; Mitchell, Faculty Status for Academic Librarians; J. Carlyle Parker, "Faculty Status and the Academic Work Year," California Librarian 33 (July 1972):143-49; Joyce Payne and Janet Wagner, "Librarians, Publication, and Tenure," College E Research Libraries 45 (Mar. 1984): 133--39; Jack E. Pontius, Cordelia W. Swinton, and Frederick van Antwerp, Faculty Status Research Requirements and Release Time (Washington, D.C.: Education Resources Information Center, 1978). ERIC ED 183147; Patricia Reeling and Beryl K. Smith, "Faculty Status: A Realistic Survey," New Jersey Libraries 16 (fall 1983): 17-25; Cynthia C. Ryans, "The Academic Status of the Professional Librarian," Ohio Library Association Bulletin 47 (Jan. 1977): 6-8; Prabha Sharma, "A SurQvey of Academic Librarians and Their Opinions Related to Nine-Month Contracts and Academic Status Configurations in Alabama, Georgia, and Mississippi," College \& Research Libraries 42 (Nov. 1981): 561-70.

9. H. William Axford, Editorial, College \& Research Libraries News 36 (Mar. 1975): 70-71; Joan M. Bechtel, "Academic Professional Status: An Alternative for Librarians," Journal of Academic Librarianship 11 (Nov. 1985): 289-92; Nancy J. Emmick, "Release Time for Professional Development: How Much Time for Research?" in Academic Libraries: Myths and Realities, ed. Suzanne C. Dodson and Gary L. Menges (Chicago: ACRL, 1984), 129-34; W. Michael Havener and Wilbur A. Stolt, "The Professional Development Activities of Academic Librarians: Does Institutional Support Make a Difference?" College \& Research Libraries 55 (Jan. 1994): 25-40; Darrell L. Jenkins, M. Kathleen Cook, and Mary Anne Fox, "Research Development of Academic Librarians: One University's Approach," Journal of Academic Librarianship 7 (May 1981): 83-86; W. Porter Kellam and Dale L. Barker, "Activities and Opportunities of University Librarians for Full Participation in the Educational Enterprise," College \& Research Libraries 29 (May 1968): 195-99; Kathleen Kenny, Linda D. Tietjen, and Rutherford W. Witthus, "Increasing Scholarly Productivity among Library Faculty: Strategies for a Medium-Sized Library," Journal of Academic Librarianship 16 (Nov. 1990): 276-79; Ronald Rayman and Frank Wm. Goudy, "Research and Publication Requirements in University Libraries," College \& Research Libraries 41 (Jan. 1980): 43-48; Diane Stine, "Research Release Time at the University of New Mexico Library," College \& Research Libraries News 43 (Dec. 1982): $380-82$.

10. Frank Wm. Goudy and Allie Wise Goudy, "The Dilemma of Library Faculty Workload: One Solution," Library Administration \& Management 2 (Jan. 1988): 36-39.

11. Shelley Arlen and Nedria Santizo, "Administrative Support for Research: A Survey of Library Faculty," Library Administration \& Management 4 (fall 1988): 208-12.

12. Virgil F. Massman, Faculty Status for Librarians (Metuchen, N.J.: Scarecrow, 1972).

13. Paula De Simone Watson, "Publication Activity among Academic Librarians," College \& Research Libraries 38 (Sept. 1977): 375-84.

14. English, "Administrators' Views of Library Personnel Status," 189-95.

15. John Campbell, "Publish or Perish, Library-Style," Wilson Library Bulletin (Nov. 1977): 52, 250.

16. Karen F. Smith and Gemma DeVinney, "Peer Review for Academic Librarians," Journal of Academic Librarianship 10 (May 1984): 87-91.

17. W. Bede Mitchell and L. Stanislava Swieszkowski, "Publication Requirements and Tenure Approval Rates: An Issue for Academic Librarians," College \& Research Libraries 46 (May 1985): $249-55$.

18. Frank J. Atelsek and Irene L. Gomberg, Tenure Practices at Four-Year Colleges and Universities. (Washington, D.C.: American Council on Education, Higher Education Panel, 1980). ERIC ED 190015. 
19. Mitchell, Faculty Status for Academic Librarians.

20. Elizabeth C. Henry, Dana M. Caudle, and Paula Sullenger, "Tenure and Turnover in Academic Libraries," College $\mathcal{E}$ Research Libraries 55 (Sept. 1994): 429-35.

21. Ibid., 433.

22. "Carnegie Foundation's Classification of 3,600 Institutions of Higher Education, Chronicle of Higher Education 6 (Apr. 1994): A18-A26.

23. Robert Boice, Jordan M. Scepanski, and Wayne Wilson, "Librarians and Faculty Members: Coping with Pressures to Publish," College E Research Libraries 48 (Nov. 1987): 494-503.

24. Ibid., 494.

25. Robert Boice, "Is Released-Time an Effective Component of Faculty Development

Programs?" Research in Higher Education 26 (May 1987): 311-26; Robert Boice and Ferdinand Jones, "Why Academicians Don't Write," Journal of Higher Education 55 (Sept./Oct. 1984): 567-82.

26. Rogers and Butler, "Academic Librarians and Faculty Evaluations," 11-17.

27. Massman, Faculty Status for Librarians.

28. Dwight F. Burlingame and Joan Repp, "Factors Associated with Academic Librarians'

Publishing in the 70s: Prologue for the 80s," in Options for the 80s: Proceedings of the Second National Conference of the Association of College and Research Libraries, ed. Michael D. Kathman and Virgil F. Massman (Greenwich, Conn.: JAI, 1981), 395-404.

29. R.. Dean Galloway, "Status or Stasis: Academic Librarians Ten Years Later," American Libraries 10 (June 1979): 349-52.

30. Charles A. Schwartz, "Research Productivity and Publication Output: An Interdisciplinary Analysis," College \& Research Libraries 52 (Sept. 1991): 416.

31. According to Mary Biggs, in many cases no distinctions have been made between scholarly research and professional publications such as book reviews, textbooks, bibliographies, or other works that do not qualify as original research to discover knowledge. Similarly, Schwartz stated that "virtually all writers on this subject point out that most listings in library science indexes refer to opinion pieces in local or institutional organs." Biggs also criticized problems of "the collapsing of authored and edited books; of equating articles in a discipline's major journals with those in obscure, low-prestige publications; the counting of books but not articles or (more often) articles but not books; unreliable or noncomprehensive means of obtaining publication lists; and failure to distinguish between sole and coauthorship. To make sense of any one study, let alone to compare studies sensibly, can be impossible." 1991): 275-89.

32. Davidson, Thorson, and Stine, "Faculty Status for Librarians: Querying the Troops," 41420; Thomas G. English, "Librarian Status in the Eighty-Nine U.S. Academic Institutions of the Association of Research Libraries: 1982," College E Research Libraries 44 (May 1983): 199-211; Becky Bolte Gray and Rosalee McReynolds, "A Comparison of Academic Librarians with and without Faculty Status in the Southeast," College \& Research Libraries 44 (July 1983): 283-87; Mitchell and Swieszkowski, "Publication Requirements and Tenure Approval Rates," 249-55; Payne and Wagner, "Librarians, Publication, and Tenure," 133-39; Pontius, Swinton, and van Antwerp, Faculty Status Research Requirements and Release Time; Rayman and Goudy, "Research and Publication Requirements in University Libraries," 43-48; Sharma, "A Survey of Academic Librarians and Their Opinions," 561-70.

33. John M. Budd and Charles A. Seavey, "Characteristics of Journal Authorship by Academic Librarians," College $\mathcal{E}$ Research Libraries 51 (Sept. 1990): 463-70.

34. Betsy Park and Robert Riggs, "Status of the Profession: A 1989 National Survey of Tenure and Promotion Practices for Academic Librarians," College \& Research Libraries 52 (May 1991): 27589.

35. Charles B. Lowry, "The Status of Faculty Status for Academic Librarians: A Twenty-Year Perspective," College \& Research Libraries 54 (Mar. 1993): 163-72.

36. Ibid., 169.

37. The Disciplines Speak: Rewarding the Scholarly, Professional, and Creative Work of Faculty, ed. Robert M. Diamond and Bronwyn E. Adam (Washington, D.C.: American Association for Higher Education, 1995); ACRL Institutional Priorities and Faculty Rewards Task Force, Academic Librarianship and the Redefining Scholarship Project (Chicago: ACRL, 1998).

38. Betsy Park and Robert Riggs, "Tenure and Promotion: A Study of Practices by Institutional Type," Journal of Academic Librarianship 19 (May 1993): 75-76.

39. Paula D. Watson, "Production of Scholarly Articles by Academic Librarians and Library School Faculty," College \& Research Libraries 46 (July 1985): 334-42.

40. Aubrey Kendrick, "A Comparison of Publication Output for Academic Business Librarians with and without Faculty Rank," Journal of Academic Librarianship 17 (July 1991): 145-47." 